[Agr. Biol. Chem., Vol. 36, No. 8, p. 1437 1439, 1972]

Note

\title{
Evidence for Specific Antibodies and Antibody-independent Inhibitors in Milk which Inhibit the Virus-induced Hemagglutination
}

\author{
By Minoru SaIto, Yoshitsugu Harada, Kazunori Mizoguchi \\ and Munehiro HIRAYAMA* \\ Central Research Laboratory, Morinaga Milk Industry Co., Ltd., Meguro, Tokyo, Japan \\ * School of Health Sciences, University of Tokyo \\ Received October 13, 1971
}

It has been documented that mammalian and avian body fluid or milk possesses inhibitors for virus-induced hemagglutination. The inhibition of virus-induced hemagglutination is postulated to be reflection of the inhibition of virion adsorption on cell surface.

Lanni et $a l .{ }^{14}$ described that cow's milk was capable of inhibiting virus-induced hemagglutination and presented a hypothesis that the inhibitory activity was attributed to a nonspecific inhibitor which is characteristic of milk rather than a specific antibody. However, the specific antibody against poliovirus has been observed in human milk by Michaels ${ }^{2}$ and Athreya et $a l .^{31}$

The purpose of this arricle is to demonstrate the inhibitory ability of human milk against hemagglutination induced by influenza virus $A_{2}$, and is to describe experimental results which suggest that this inhibitory activity in human milk mainly depends on antibodyindependent, non-specific hemagglutination inhibitors.

Human colostrum and transitional milk, which were obtained from individual mothers 1 to 10 days after parturition, were centrifuged to eliminate fats and lyophilized. Samples of cow's milk, directly supplied from a dairy farm, were used without pasteurization for the experiment and were also centrifuged to eliminate fats and lyophilized. Influenza virus $\mathrm{A}_{2}$ (Adachi), used in this experiment, was propagated in chiken egg allantoic fluid and harvested by centrifugation. The virus suspension was adjusted to the virion density which reveals hemagglutination activity even after 3 fold dilution; the activity is last by 4 fold dilution. ( 3 to 4 hemagglutination units).

Aliquots of $0.25 \mathrm{ml}$ of the virion suspension of 3 to 4 hemagglutination doses were incubated for $30 \mathrm{~min}$ at $0^{\circ} \mathrm{C}$ with the same volume of the inhibitor solution which had been sequentially diluted and $0.5 \mathrm{ml}$ of $0.25 \%$ chicken red cell suspension was added to the incubation mixture. The inhibition titer of the inhibitor solution was expressed in terms of the reciprocal of the maximum dilution index which is able to inhibit the hemagglutination. Dilution of the inhibitor fluid was carried out with a sterilized physiological saline throughout.

Fractionation of human milk was carried out through precipitation by means of ammonium sulfate followed by dialysis and lyophilization according to an analogous procedure as employed in the purification of the globulin fraction of cow's milk ${ }^{4,5}$ as shown in Fig. 1. Inactivation of the inhibitor by receptor destroying enzyme ( $\mathrm{RDE}$, a lyophilized filtrate of a Cholera vivrio culture containing Penicillin $G$ potassium salt and Streptomycin) was achieved by incubating $0.25 \mathrm{ml}$ of the inhibitor fluid $(8 \mathrm{mg} / \mathrm{ml}$ ) with $0.25 \mathrm{ml}$ of RDE (purchased from Takeda Chemical Co.) for $18 \mathrm{hr}$ at $37^{\circ} \mathrm{C}$ and then for $30 \mathrm{~min}$ at $56^{\circ} \mathrm{C}$. The RDE solution was prepared by diluting one vial quantity with $40 \mathrm{ml}$ of the physiological saline.

Trypsin (purchased from Sigma Chemical 


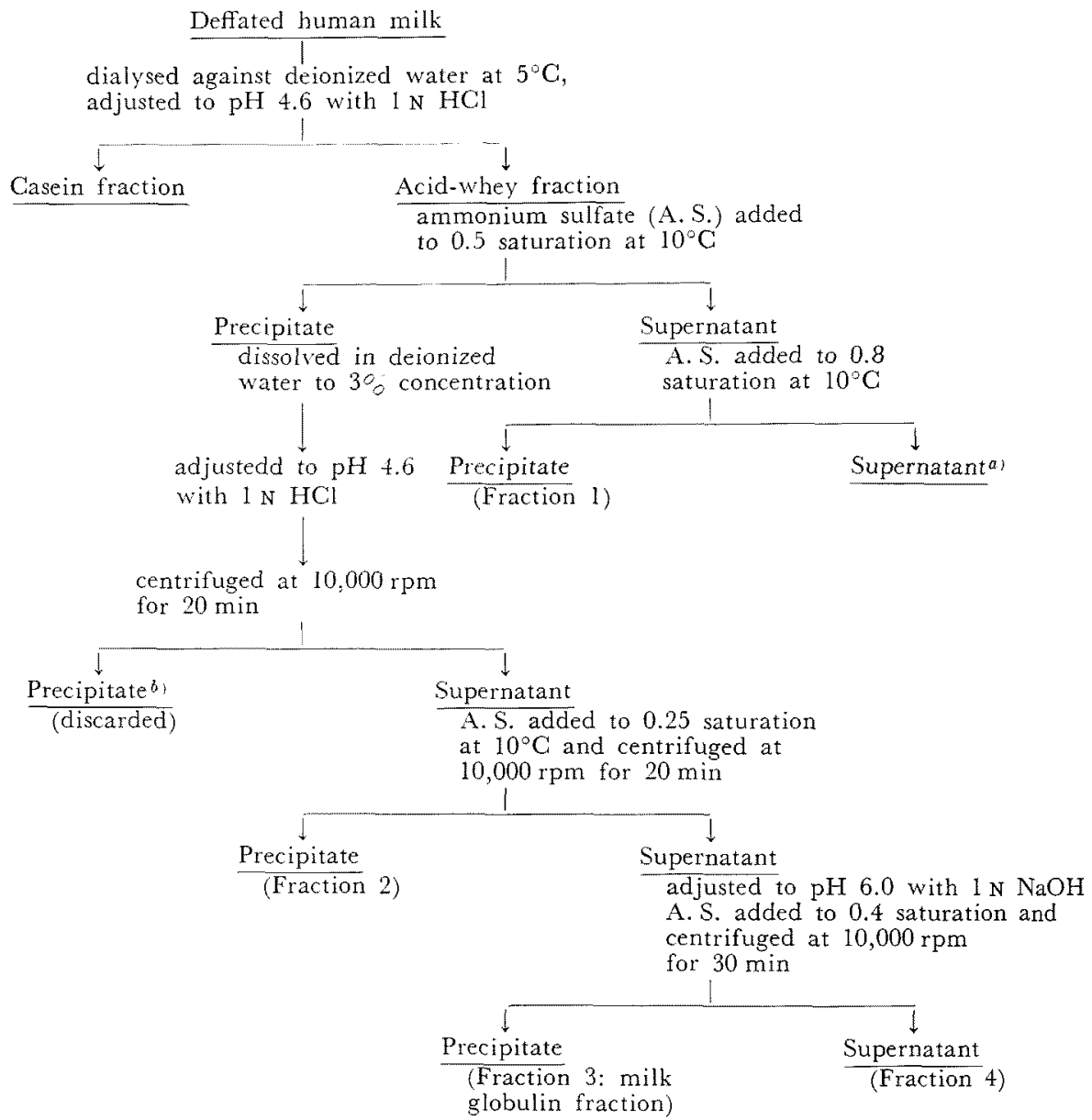

FIG. 1. Fractionation Procedure of Human Milk.

Every fraction was dialysed against water and then lyophilized.

a) HI values per mgN was lower than 2 .

b) considered as casein fraction

Co.,) was dissolved in $0.01 \mathrm{~N} \mathrm{HCl}$ to give a concentration of $40 \mathrm{mg} / \mathrm{ml}$ and from the solution dilution was made with $0.1 \mathrm{M}$ veronal buffer of $\mathrm{pH} 8.2$ to prepare a solution of $8 \mathrm{mg} / \mathrm{ml}$ immediately before use.

In an experiment to examine the effect of $\mathrm{KIO}_{4}$ on the inhibitory activity, $0.5 \mathrm{ml}$ of $0.01 \mathrm{M} \mathrm{KIO}_{4}$ was added to $0.25 \mathrm{ml}$ of the inhibitor fluid and the mixture incubated for $16 \mathrm{hr}$ at $4^{\circ} \mathrm{C}$, followed by addition of $0.25 \mathrm{ml}$ of $1, \%$ glycerine in order to terminate the reaction.

Profile of transition in the inhibitory activity of human and cow's milk against hemagglutination is presented in Table $I$ as a function of days after perturition. The inhibitory activity was significantly higher in human milk from individuals on fourth day after parturition than that of later days.

Specificity of the inhibitory activity of human milk was examined in a comparative study with cow's milk. The activity in cow's milk 
TABLE I. INHIBITORY ACTIVITY OF HUMAN AND Cow's MILK against HEMagglutination By INFLUENZA $A_{2}$ virus.

Each value is expressed as a mean of five determinants.

\begin{tabular}{cccc}
\hline $\begin{array}{c}\text { Milk } \\
\text { source }\end{array}$ & $\begin{array}{c}\text { Day after } \\
\text { parturition }\end{array}$ & $\begin{array}{c}\text { HI value/ } \\
\text { mg-weight }\end{array}$ & $\begin{array}{c}\text { HI value/ } \\
\text { mgN }\end{array}$ \\
\hline \multirow{3}{*}{ Human } & 3 & 32 & 551 \\
& 7 & $\frac{1}{2}$ & 144 \\
& 8 & 2 & 69 \\
\hline \multirow{2}{*}{ Cow's } & 1 & 8 & 108 \\
& 7 & 8 & 99 \\
& 8 & 4 & 73 \\
& 9 & 4 & 75 \\
\hline
\end{tabular}

was found to be $1 / 2$ to $1 / 5$ that of human milk. The discrepancy in the activity between human and cow's milk was particularly remarkable in the colostrum.

Migration of poliomyelitis antibody from serum into milk was demonstrated by $\mathrm{Mi}-$ chaels $^{2}$ and Athreya. ${ }^{31}$ The authors' interest was focused on the elucidation of whether the inhibitoroy activty in human milk against hemagglutination by influenza virus is derived from a specific antibody or a non-specific inhibitor in human milk. It has been established that the criteria for antibodies is their insusceptibility to RDE, trypsin and $\mathrm{KIO}_{4}$ reagents. ${ }^{6,7}$ Human milk was, therefore, fractionated into 5 fractions by means of ammoninm-sulfate precipitation (Fig. 1) and susceptibility of the inhibitory activity in the fractions against these reagents was tested.

The experimental results revealed that the inhibitory activity is not restricted in globulin fraction (Fraction 3), but rather distributed among the four fractions. It is probable that a portion of the activity in Fraction 3 is attributed to antibody, and each activity in Fractions 1,2 and 4 seems to be derived from nonspecific inhibitors because of their modes of the responses to the reagents (Table II).

Non-specific inhibitors in Fractions 1 and 4 can be assigned as inhibitors and those in Fraction 2 seemed to be $\alpha$ inhibitors according to
TABLE II. RESPONSE OF INHIBITOR ACTIVITY IN Fractions of Human Milk to RDE, Trypsin AND $\mathrm{KIO}_{4}$ REAGENTS.

\begin{tabular}{lrccc}
\hline Fractions & $\begin{array}{c}\text { HI values/ } \\
\text { mgN }\end{array}$ & RDE & Trypsin & $\mathrm{KIO}_{4}$ \\
\hline Casein & 348 & + & \pm & + \\
Acid-whey & 2948 & + & + & - \\
Fraction 1 & 1392 & - & - & + \\
Fraction 2 & 28 & + & \pm & + \\
Fraction 3 & 1076 & - & - & \pm \\
Fraction 4 & 1516 & \pm & - & + \\
\hline$+:$ Inhibitory activity was diminished by the treat- \\
ment. Inhibitory activity was not diminised by the \\
$-:$ In we \\
treatment.
\end{tabular}

the classification of non-specific inhibitors which is based on the mode of the response to the reagents $s^{6,7)}$ above described. It is generally accepted that the specific antibodies in human milk operate as inhibitors against virus multiplication in the intestine of infants fed with breast milk. It is also a plausible hypothesis that antibody-independent and nonspecific hemagglutination inhibtors, found in human colostrum to a higher activity than in cow's milk, might influence the inhibitory effect against absorption of virus to their intestinal cells.

The authors are deeply obliged to kind advices by Dr. Taro Nagasawa, Director of the Laboratory, and Dr. Akira Sugiura of the Institute of Public Health, Japan. Samples of human milk are kindly supplied from Dr. Tadao Nakajima of the Maternary Hospital of Japan Red Cross, Tokyo, Japan.

\section{REFERENCES}

1) F. Lanni, V. T. Lanni and J. W. Beard, Proc. Soc. Exptl. Biol. Med., 72, 227 (1949).

2) R. H. Michaels, J.Immun., 94, 262 (1956).

3) B. H. Athreya, L. L. Coriell and J. Charney, J. Pediat., 64, 79 (1964)

4) E. L. Smith, J. Biol. Chem., 164, 345 (1964).

5) E. L. Smith, ibid., 165, 665 (1964).

6) N. Higashi, N. Ishida, Virology (Asakura Publish 452 (1967).

7) A. Sugiura, Virus, 9, $138(1959)$. 